\title{
A Case of Mixed Motives? Formal and Informal Functions of Administrative Immigration Detention
}

\author{
A. Leerkes \& D. Broeders, Erasmus University Rotterdam
}

Published in British Journal of Criminology 50 (5): 830-850.

\section{Introduction}

All over Europe new detention centres for immigrants are being or have been built in recent years (Gibney and Hansen 2003; Weber and Bowling 2004; Jesuit Refugee Service 2005; Welch and Schuster 2005; Calavita 2005; De Giorgi 2006; Van Kalmthout et al. 2007). In the United States as well, there has been a 'surge in the numbers of undocumented immigrants incarcerated in county jails, federal prisons and immigration detention centers' (Inda 2006: 116; see also Scalia 2002; Ellermann 2005; Amnesty International 2009). Australia also has a notable capacity to detain asylum seekers and illegal migrants (Burke 2008). In other words, detention of 'unwanted' migrants is increasingly part and parcel of the governmental regulation of international immigration.

There are two main types of immigration detention (Hailbronner 2007; Cornellise 2010): (1) pre-admission detention at the border involving foreigners not admitted to the state's territory - in some countries this includes asylum seekers - and (2) pre-expulsion detention of foreigners whose stay in the territory is or has become unauthorized (hereafter: illegal migrants). This article primarily pertains to the second type of immigration detention.

In most European countries, including the Netherlands, the detention of migrants for these migration-related reasons is defined as administrative detention, a detention modality that is formally not a punishment, and does not require a conviction for a crime. It is a matter of administrative and not criminal law. Although law stipulates that it be imposed in the interest of 'public order and national safety', administrative immigration detention is defined as a non-punitive, bureaucratic measure that is meant to enable the enactment of border control: it merely ensures that 'unwanted' migrants can be located 
and identified and cannot abscond while the expulsion is prepared (cf. Noll 1999: 268). Given this rationale, immigration law prescribes that confinement has to be annulled as soon as the migrant's departure has been organised, or if an administrative judge decides that the chances of expulsion are too slim to justify continued detention. ${ }^{2}$

The question can be raised whether the formal policy framework for administrative immigration detention, in which detention is a non-punitive means to achieve the goal of removing unwanted migrants, constitutes a sufficient explanation for actual detention practices. In this paper we will be looking more closely at the case of the Netherlands where it appears that immigration detention serves informal social functions that are not codified in law.

There are three main empirical observations in the Netherlands that warrant an examination of de facto functions of immigration detention. Firstly, since the early 1990s up to 2006 , there has been a steady increase in the capacity and actual use of immigration detention, while the number of expulsions appears to have been going down. It was only after 2006 that detention figures decreased somewhat, mostly as an indirect effect of the EU's enlargements in 2004 and 2007, which legalised many Eastern European illegal migrants over night. Secondly, the average length of immigration detention in the Netherlands has increased over the years (Van Kalmthout and van Leeuwen 2004a, 2004b). Thirdly, if expulsion procedures fail, immigrants are released from detention, back on the streets. In the informal lingo in the field of immigration detention this practice has become known as klinkeren - which roughly translates into 'cobbling', i.e. releasing somebody back onto the cobblestone streets. 'Cobbled' detainees are often reapprehended and detained again in case of continued illegal residence. ${ }^{3}$ To these practically 'undeportable deportable immigrants', the detention system risks becoming a revolving door (Leerkes, 2009; Broeders 2009, 2010).

Localisation, identification and documentation of illegal migrants are a sine qua

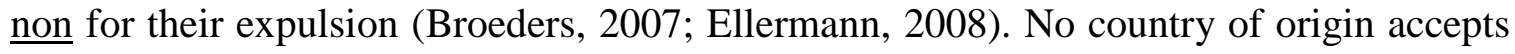
undocumented returnees. Identification with a view to (re-)documenting an illegal migrant, takes place during administrative detention. The observations above indicate that the immigration authorities have great difficulties with the identification of illegal migrants who are reluctant to be sent home, hide their legal identity and have destroyed 
their papers (Broeders, 2010). Countries of origin too may be reluctant to co-operate with repatriation. The International Organization for Migration (2008: 94), for example, reported that Chinese who have stayed in Western Europe for a longer period of time, "are often not allowed back into China, as Chinese authorities fear that their experience of democracy may make them dangerous." Thus, identification and compliance by countries of origin are the main bottlenecks of the expulsion procedure.

Because of these apparent irrationalities from the perspective of the official legal framework - why increasingly invest in immigration detention, if it does not lead to more expulsions? - it is worthwhile to explore other explanations for the use of immigration detention. Certain 'irrational' practices may make sense for certain actors when looked at through a different lens. As has been said, these alternative perspectives are unlikely to be codified in law. What interests us here are immigration detention's implicit or informal functions, i.e. the various de facto uses that it may have for relevant actors in this social field, such as national and local politicians, policymakers, policemen, immigration judges, and illegal migrants.

There is an extensive scientific literature on the functions of penal detention (for overviews see Rycklak 1990; Garland 1991, Carlsmith and Darley 2002). This literature provided the 'sensitizing concepts' (Blumer 1954)) that helped us identify relevant informal functions of immigration detention. The study's empirical basis consisted of policy documents, survey data, administrative data, and fieldwork in a Dutch centre for immigration detention. Empirical observation is crucial to avoid the fallacy of functionalism, i.e. the idea that practice $\mathrm{Y}$ must necessarily be functional for actor Z, given interest $\mathrm{X}$, simply because $\mathrm{Y}$ can be expected to exert certain beneficial effects for $\mathrm{X}$. It is desirable to demonstrate these effects empirically, for instance by showing that $\mathrm{Z}$ aimed for Y because of X (Levy 1968).

To some extent our distinction between formal and informal functions of immigration detention resembles Robert Merton's (1957) classic distinction between 'manifest' and 'latent' functions. Yet, whereas Merton stressed the unintended nature of latent functions, we allow for the possibility that some informal functions of administrative detention may be intended by the actors in that social field - politicians, policymakers, policemen, immigration judges, illegal migrants - even if such motives are 
not formalised in law. Thus, detention practices will be analysed "in relation to specific interests, specific social relations, and particular outcomes - bearing in mind what is 'functional' from one point of view may be dysfunctional from another" (Garland 1991: 126).

In the next section we briefly describe the main functions of penal detention that emerge from the academic literature. We next describe the main characteristics of administrative immigration detention in the Netherlands. In the remainder of the article we explore three possible informal functions, and present some suggestive evidence for each. These alternatives are (1) deterring illegal residence, (2) controlling the negative external effects of (illegal migrant) pauperism and (3) asserting symbolical control over unwanted immigration with a view to upholding popular support and trust in national government.

\section{Functions of penal punishment}

The social scientific literature argues that, on the one hand, punishment is meant to reduce deviance. Or, to be more precise, it can be said that practices of punishment are functional for the ideology that punishment decreases deviance, as there is considerable scholarly disagreement on the effectiveness of punishment in reducing deviance. This instrumental or utilitarian function of punishment includes notions of deterrence (punishment and the threat of punishment inhibit crime), rehabilitation (prisons resocialize convicted offenders to prepare for their re-integration in society), and incapacitation (crime levels can be controlled by removing dangerous individuals from society). On the other hand, it is argued that punishment satisfies certain moral needs, regardless of its real or perceived effects on deviance levels. This expressive or deontological function of punishment includes notions of retribution (wrongdoers deserve punishment proportional to the moral wrong committed) and denunciation (law trespassers should be held up to the rest of society and denounced as violators of the rules that define what the society represents (cf. Rychlak 1990: 331)).

Admittedly, the functions mentioned are to some extent informal. For example, criminal law and penal law do not state that punishment is meant to deter or incapacitate. 
Yet, contrary to administrative law, most of the functions mentioned are clearly implied in criminal and penal law, and are widely agreed upon in the legal and penal field.

Many criminologists have noted and debated shifts in penal policies and practices concerning the functions of punishment. Under the headings of the 'new penology' (Feely and Simon 1992) and the 'culture of control' (Garland 2001) scholars have noted that ideals and practices of rehabilitation, which were central to penal practices during the 1960s and 1970s, have gradually given way to stricter and harsher policies that place the emphasis on incapacitation. Even though these theories have also met with various critiques (see for example Matthews 2005; Cheliotis 2006; Reiner 2007) the shift from rehabilitation to a focus on incarceration remains a central hypothesis. One of the main indicators for this development has been the rising incarceration rates in Western Europe and North America (Feeley and Simon 1992; Wacquant 1999)

Another claim of the new penology is that the net of the penal system has been cast wider. It has begun to target a wider range of 'dangerous' social groups apart from the individual criminal. Or, in the words of De Giorgi (2006: 106): '[i]t is not so much the individual characteristics of subjects that are the object of penal control, as instead those social factors which permit to assign some individuals to a peculiar risk-class.' In this way, groups that formerly were in the care of the welfare state or private charities, such as the poor, welfare dependents, and drug addicts are increasingly coming into contact with the penal system.

In this article we will go into the question of whether the development described by the new penology is relevant in the case of illegal migrants in the Netherlands, as administrative immigration detention only started in earnest in the early 1990s. This roughly coincides with the period in which the shift from rehabilitation to incapacitation is supposed to have occurred. We will also relate the other functions of punishment to immigration detention practices in the Netherlands.

\section{Immigration detention in the Netherlands}

In the Netherlands, as in many other EU member states, expulsion policies have become more prominent in recent years. Even though expulsion remains in essence a solution of 
last resort - voluntary departure is certainly preferred over expulsion - it has come to be regarded as the indispensable closing section of any serious restrictive immigration policy, which certainly characterises the Dutch policy with respect to non-EU nationals. In 2003 the Dutch White paper on Return even stated that 'return policy should not be a closing section but rather an integral part of immigration policy itself' (Minister voor Vreemdelingenzaken en Integratie 2003: 5).

In the majority of the EU countries, including the Netherlands, illegal residence is, in itself, not a criminal offence, meaning that there is no ground under criminal law for detention (for a legal study on immigration detention in Europe see Cornellise 2010). In a smaller group of EU countries ${ }^{4}$, including Germany, illegal residence is a criminal offence that is usually punishable with fines and detention (Van Kalmthout et al. 2007: 64). Yet, even in Germany, immigration detention usually is administrative detention and does not take place under criminal law (Dünkel et al. 2007: 377).

The legally allowed length of administrative detention in the Netherlands is long when compared to most other European countries. Whereas in some countries administrative immigration detention is a matter of days, Dutch law has no fixed duration (Van Kalmthout et al. 2007: 59). In principle detention can be imposed until expulsion is realised or still remains a possibility. In light of the recent adoption of the European 'Returns Directive', which stipulates that the maximum length of administrative detention shall not exceed 18 months, Dutch law will have to be adapted (Baldaccini 2009). Considering that the maximum was set at 18 months, detention practice will not have to change much as detentions of that length are exceptional, although they do occur (Van Kalmthout \& Hofstee-Van der Meulen 2007: 650). At present, roughly $75 \%$ of the total population is detained for less than three months (DJI 2008a: 13).

The legal framework for administrative detention has been translated into a detention practice that suggests that the Dutch authorities have great confidence in detention for the regulation of migration. During the 1990s the cell capacity for immigration detention has been greatly increased. While in 1980 there were 45 places available for the administrative detention (Van Kalmthout 2005) in 2007 the counter stopped at 3,807 places (DJI 2008b; see also figure 1). If we look at immigration detention as a percentage of the total prison capacity (i.e. excluding youth facilities and 
enforced mental healthcare) the share of immigration detention has risen from $9.1 \%$ in 1999 to $18.1 \%$ in 2006 (Broeders, 2009).

The actual use of immigration detention has also become more prevalent in this period. On September $30^{\text {th }} 1994$, there were 425 administratively detained immigrants, against 2,555 on September $30^{\text {th }}$ 2006. In this period, the annual number of administratively detained immigrants increased from 3925 to $12480 .^{5}$

[Figure 1 somewhere over here]

Most detainees in the Netherlands are in pre-expulsion detention. Pre-admission detention is relatively uncommon: asylum seekers are housed in open reception centres spread across the country, and human smuggling is less of an issue than in countries bordering poorer non-Western countries. Almost all administratively detained immigrants are adults (>99\%), about two thirds of whom are between 18 and 35 years of age. Men predominate (90\%). Diversity in educational backgrounds is substantial: detention surveys held in 2004 and 2007 (see below) yielded the following distribution: 25\% of the detainees had no formal education, $15 \%$ had primary education, $40 \%$ had secondary education and $25 \%$ reported having completed tertiary education. Thus, the share of the latter educational level was clearly elevated in comparison with regular prisons, which stood at $11 \%$ in 2007 . These figures confirm that it is not only, and not even primarily, the poorest who migrate to Western countries (De Haas 2005). Diversity in nationalities is substantial as well: in 2009, according to Ministry of Justice registrations, the majority of the administratively detained immigrants were born in countries that, on their own, represented less than $5 \%$ of the detained population. The most prevalent country of birth was Somalia (12\%). ${ }^{6}$ This variation in national backgrounds resembles the diversity of the unauthorized population in the Netherlands, in which over two hundred nationalities are represented. This includes countries that have been a source of immigration for some time now (Morocco, Turkey, China and Surinam, a former colony), 'new' countries of labour migration to the Netherlands (Ukraine, India, Philippines), 'asylum countries' (Somalia, Iraq, Afghanistan), and countries that play an important role on the international 'spouse market' (Brazil, Thailand, Russia) (Leerkes, 2009). 
The increased use of immigration detention contrasts with the figures on expulsions, which appear to be on the downturn since the early 2000s. Perhaps tellingly, there is no official publication in the Netherlands reporting on expulsion trends. Thus, in order to create a time series, we had to 'excavate' relevant figures from various periodic reports by the Ministry of Justice. The results, depicted in Figure 1, indicate that the number of expulsions has been dropping since 2002, from a peak of 12,015 deportations in that year, to 6,150 deportations in 2007.

There is additional evidence indicating that the Dutch authorities have great difficulty expelling detainees. According to Dutch Immigration Services (IND) statistics, immigration detention resulted in expulsion for $60.7 \%$ of all detainees in 2000 and for 56.9\% in 2001 (ACVZ 2002: 23). On the basis of his research among 400 immigrant detainees in 2003-2004 Van Kalmthout (2007: 101) claims the percentage of illegal migrants who are actually expelled is lower and may even be below $40 \%$.

Clearly, although the official rationale for administrative immigration detention explains part of detention practices - expulsions do certainly take place -, it does not give a full explanation of immigration detention practices. Given the persistence - and widening - of the gap between the large investments in immigration detention and the declining 'proceeds' thereof in terms of expulsions, the policy does seem to lack rationality. Therefore, other explanations for the practice of the administrative detention should be considered.

\section{Deterring illegal residence}

Although immigration detention is formally not a punishment, there are strong indications that detainees may experience it as a punishment nonetheless. It may even be hypothesised that administrative detention is meant to be experienced as a punishment, even if politicians and policymakers seldom state this intention explicitly.

Other researchers have already asserted that administrative immigration detention is meant to bring about specific deterrence (Van Kalmthout et al. 2007: 53). In this view, the regime of administrative detention is intended to increase the pressure on detainees to leave the country and co-operate with the expulsion procedure, just like criminal 
detention is intended to pressure criminals into law-abiding behaviour. We expand this view by proposing that immigration detention may also be intended as a form of general deterrence. In the latter sense, the perceived threat of administrative detention is meant to deter potential unwanted migrants from violating migration and residence laws, just like the threat of criminal detention is supposed to suppress criminal behaviour in the noncriminal population.

One important reason for the claim that Dutch immigration detention is intended to be punitive is that the regime is modelled after the model of voorlopige hechtenis, i.e. the detention regime for suspects of serious crimes who are put in custody while awaiting their trial. As a consequence, the administrative detainee has to undergo a similar extent of deprivation as suspected serious criminals, when it comes to opportunities to communicate with the outside world, work, daily routine, choice of food, et cetera.

It could even be argued that administrative immigration detention is more of a punishment than staying in a regular prison, as the actual level of deprivation and degree of separation from local communities are probably higher in the former type of regime (with duration of stay held constant). For instance, although administratively detained immigrants have a right to be visited by family members or volunteers, they have no right to be visited without supervision, which, if it is considered beneficial for the rehabilitation of convicts, is allowed in some prisons. Furthermore, contrary to regular prisons, it is impossible to leave the immigration detention centre under supervision in order to attend important family events, such as attending the funeral of a direct family member. Moreover, in comparison with regular Dutch prisons, immigration detention centres in the Netherlands are characterised by a significantly lower level of facilities when it comes to work and schooling opportunities, sport facilities, and single person cells. All centres have some sporting facilities and some type of day program, but contrary to regular prisons, work opportunities are not always available. Also, it has been noted that there is often a relative lack of medical and legal aid, a risk of overcrowding, and fewer well-qualified staff (Dünkel et al. 2007; Van Kalmthout and Hofstee-Van der Meulen 2007). Given these differences, it is not surprising that a place in administrative detention is about 20 per cent cheaper than a place in a regular prison. ${ }^{7}$ 
It could be argued that the elevated level of deprivation in administrative detention in comparison to regular prisons follows from the formal policy framework and cannot be taken as an indication that immigration detention is used for deterrence purposes. It could be argued, for example, that the relative lack of work and study opportunities in administrative detention is consistent with the objective to expel the detainee: the illegal migrant is, by definition, not supposed to re-integrate in regular Dutch society.

However, there is ample evidence that politicians and policymakers do use administrative detention for deterrence purposes. For example, Mr Nawijn, a former Dutch Minister of Aliens Affairs and Integration ${ }^{8}$, referred to this function explicitly when the Dutch parliament discussed the Ministry of Justice's budget for 2003, which included an increased budget for tracing and detaining illegal migrants: "The intensification of Aliens Surveillance will work from two sides. Because of the actual surveillance, when illegals are found and then removed, the number of illegals will decrease [AL/DB: here Mr. Nawijn refers to the formal function of immigration detention]. Furthermore, the realisation that there are more intensive controls -and that, therefore, the apprehension chance is increased- will have a deterrent and, therefore, preventive effect [AL/DB: here Nawijn hints at the informal general deterrence function we hypothesise, even if he does not speak of detention as such]." (Tweede Kamer 2002: 142; emphasis added).

There is one further indication that national politicians and policymakers became increasingly motivated in the late 1990s and early 2000s to use criminal law and the threat of detention to deter unwanted immigrants from the Netherlands: since 2000 in particular, there has been a marked increase in 'undesirable aliens' resolutions in the Netherlands. An illegal migrant who is apprehended repeatedly for illegal residence, or who has been convicted of certain crimes, can be declared an undesirable alien by The Ministry of Justice (legal migrants can also be declared undesirable aliens on the latter ground). Continued residence in the Netherlands as an undesirable alien is then regarded as a crime against the state, which can be punished with six months of imprisonment (usually three months). The annual number of undesirable aliens resolutions increased from 845 in 2001 to 1,567 in 2006, and the annual number of convictions because of 
continued residence by undesirable aliens increased from 480 to 848 in this period (Laagland et al. 2009).

It is unknown to what extent administrative detention is effective in deterring illegal residence. On the one hand, we know that administratively detained migrants in the Netherlands are substantially less satisfied about being imprisoned than regular prisoners. Moreover, it appears that the elevated level of deprivation in the immigration detention regime is among the principal reasons for the reduced level of detention satisfaction. This conclusion is based on the prison and immigration detention surveys that were conducted by the Ministry of Justice in 2004 and 2007. ${ }^{9}$ Our secondary analyses show that the difference in imprisonment satisfaction between immigration detention centres and regular prisons is most marked for males. On an ordinal scale of 1 to 5 , males in immigration detention centres rated their general satisfaction with the institution with an average of 2.1 (2004 and 2007 combined), against 3.0 for regular prisoners (2007) (See Figure 2). For women, these figures were 2.7 and 3.1 respectively. Similarly, we find that a significantly elevated percentage of administratively detained females - and even more so for male detainees - reported having felt unsafe while being detained (Figure 3). These gender differences are consistent with the fact that the detention regime for administratively detained women is less restrictive than for their male counterparts. For instance, female detainees are less likely then male detainees to share a cell with more than one person, and more likely to have access to a shower of their own. ${ }^{10}$ Moreover, in some centres for women, the detainees are allowed to do their own cooking and have their children with them.

The differences between immigration detention and regular detention tend to be most pronounced for precisely the dimensions of detention satisfaction where administrative detention centres are objectively outperformed by regular prisons (see the dimensions 'quality of activities', and 'ability to enjoy oneself' in Figure 2; see note for details on the scales as there is even reason to think that the scores on 'quality of activities' are an underestimation of the actual difference between regular prisons and the Aliens Custody). ${ }^{11}$

On the other hand, there is no evidence that unwanted migrants are leaving the Netherlands in large numbers because of increased detention and expulsion risks. The 
most recent study on the size of illegal residence in the Netherlands found a decrease in the number of illegal migrants between 2002 and 2005, but attributed that finding mainly to the EU's expansion in 2004 (Van der Heijden et al. 2006).

\section{Managing the external effects of poverty}

In the Netherlands, illegal migrants are excluded from formal welfare arrangements and (most) health care, since the Koppelingswet ('Linking Act') was implemented in 1998. As a consequence, illegal migrants who stay in the Netherlands in spite of its increasingly restrictive policies with regard to illegal residence have become dependent on informal social safety nets in case of unemployment, homelessness and/or illness. Moreover, the aforementioned restrictive policies also seem to increase the extent to which illegal migrants come to depend on relief as such: illegal migrants' labour market and housing market position deteriorated as a consequence of the Koppelingswet and other restrictive measures. ${ }^{12}$ This policy-driven increase in social exclusion appears to have resulted in more marginalisation and a rise in (petty) crime among illegal migrants in the Netherlands (Leerkes 2009; Leerkes and Bernasco, 2010).

In spite of this restrictive legal framework, and partly because of it, substantial numbers of illegal migrants manage to be supported by non-governmental organisations. A 2002 case study in The Hague and Leiden revealed that there was considerable solidarity with illegal migrants at the local level (Rusinovic et al. 2002; Van der Leun 2003). A highly varied group of churches, civil initiatives, migrant organisations, leftwing activists and civil servants expressed support for illegal migrants. These institutions and individuals tended to specialise in the support they offered. Some donated meals, while others gave legal advice or information about health care, arranged temporary accommodation, or offered language courses.

Interestingly, local governments - faced with the results of restrictive immigration policy in the form of homeless and criminal illegal migrants on their streets - have also begun to offer relief to specific categories of illegal migrants. For instance, many municipalities subsidise accommodation or have begun to organise accommodation themselves. According to an inventory by the VNG, the association of Dutch 
municipalities, 170 of the approximately 400 municipalities offered such support in direct or indirect ways, from which more than 2,000 persons benefited (Van der Leun 2004). Such municipal support is largely aimed at asylum seekers whose applications have been turned down.

Yet these local networks are quite loose and unorganised. Each of the individuals and organisations involved tries to take care of a small part of the demand. Moreover, not every applicant can be helped, as resources are limited. The organisations have to be selective and are forced to set criteria determining who may or may not be helped. The old distinction between the deserving poor and undeserving poor tends to return under these circumstances. Rejected asylum seekers, i.e. refugees, have a greater chance of being helped than other groups of illegal migrants such as 'economic adventurers'. This is the case with municipal support, but also for support by churches. Women and children are helped more often than single men.

Thus, there is a growing group of vulnerable illegal migrants in the Netherlands, composed of people who cannot find sufficient employment, do not have a family or partner to support them, and are to a great extent excluded from the informal social safety nets that NGO's and municipalities have developed. They are increasingly declared undesirable aliens due to repeated illegal residence, more or less serious criminal activities, or a combination of the two. The size of this group is unknown, but is believed to vary between several hundred and several thousand individuals. They are mostly, but not exclusively, adult males.

A considerable number of the members of this group are difficult to expel, because, as has been said, they manage to keep their identities secret, but also in part because countries of origin appear to be reluctant to take such marginalised illegal migrants back. They are also less likely to be granted residence rights under legalisation programmes which tend, in the Netherlands and elsewhere, to exclude migrants who have been convicted of crimes. Set against the background of previous regularisations in the Netherlands - there have been a few regularisations, but these were limited and politically contested - this group's chances for regularisation are negligible.

For these reasons, we hypothesise that detention - criminal detention as well as immigration detention - may also be used as a form of 'relief of last resort' for such 
strongly marginalised illegal migrants. The aforementioned forms of crime and public order disturbances generate anxieties among the established population, but are often not serious enough to lead to criminal imprisonment. In the general population such forms of deviance, such as homelessness, are often taken care of by social workers, or by means of granting unemployment benefits, but for illegal migrants that is increasingly impossible.

As will be elaborated below, our research suggests that the authorities as well as marginalised illegal migrants themselves contribute to the use of detention as a form of poor relief, albeit for different reasons. The authorities, including local policemen, use detention to relieve public order disturbances that are associated with immigrant pauperism. Seen from this perspective, it is noteworthy that the Dutch Expulsion Centres in Rotterdam and at Schiphol airport were introduced under the banner of a government program that was called 'Towards a safer society'(Den Hollander 2004: 160). And a recent report by the Ministry of Justice (2009: 9) describes its program 'expelling / detaining' as follows: "[a]ll efforts are aimed at expelling criminal and/or nuisancecausing illegals, and, if that is not yet possible ... to detain them in order to take away the nuisance for society". In other words, it seems that Dutch authorities increasingly use immigration detention (and criminal detention) for incapacitation purposes, and not only as a measure of immigration policy.

We have already mentioned the increased average length of stay in administrative detention and the common use of 'cobbling', which may lead to repeated administrative detention. These practices may be the result of the informal function of deterring illegal residence, but are also consistent with the interpretation that administrative detention is used to relieve pauperism and its external effects. During our own fieldwork in the Immigration Detention Centre in Tilburg, which was conducted in 2005, we also found qualitative support for the latter hypothesis (for details on this fieldwork see Leerkes 2009). Several of the 26 men who were interviewed - only men who had been convicted of crimes in the Netherlands were selected for an interview - turned out to have been in immigration detention more than once. The clergymen and psychologists working in the institution turned out to know some of them quite well from previous stays. Institution staff members also told us that undesirable aliens are sometimes put in immigration 
detention by the police in the big cities during special festivities in town such as Koninginnedag, the national celebration of the Dutch queen's birthday.

Strongly marginalised illegal migrants, on their part, sometimes seem to 'use' detention - this goes for criminal detention and immigration detention - as a temporary relief for their lives outside of the detention centre. Most illegal migrants whom we interviewed found immigration detention a difficult and denigrating experience, which reflects the reduced level of detention satisfaction in administrative detention (Figure 2). At the same time, some respondents judged it less negatively. An undesirable alien from Iran, who had for years been part of a group of street drug-users in a deprived neighbourhood in Amsterdam, claimed that he sometimes pleaded guilty to offences he had not committed in order to recover in detention from his life on the streets. Staff members also claimed that detainees sometimes preferred a stay in immigration detention to life on the streets. Reputedly there was even a case where a detainee who had been cobbled because no laissez passer could be obtained, set up camp in the bushes next to the institution.

The latter impression may also be confirmed by Figure 2. Note that the difference in detention satisfaction between administrative and criminal detention is relatively small or non-existent for aspects of detention that may be related to poor relief (material aspects, hygiene, health care). It may also be that women, in particular, find relief and protection in centres for immigration detention.

In some respects, these practices share similarities with the poorhouses of the past, particularly the earliest variants such as the houses of correction or workhouses. The latter institutions were also meant to control the external effects of pauperism and were similarly characterised by a strong measure of social control and repression (Katz 1986; Wagner 2005). The current detention practices, however, are directed at aliens, at 'outsiders', and not at insiders. Contrary to the poor houses of the past, the present detention centres are not supposed to reform and discipline 'idle' illegal migrants into labour. Rather, they are kept off the streets as much as possible. This difference may also explain why labour is not mandatory in immigration detention. 
In short, it appears that immigration detention has become a system of control that incapacitates marginal populations, while ideas of rehabilitation and correction disappear into the background. This is in line with the new penology hypothesis.

\section{Managing popular anxiety and symbolically asserting state control}

International migration - especially migration from poorer non-EU countries - has become a highly politicised topic throughout Europe, including the Netherlands. While considerable parts of the established population continue to press for more restrictive policies, other groups advocate a more liberal migration regime. After years of intense debate the Dutch government regularised about 30,000 rejected asylum seekers in 2008. In general, however, public opinion in the Netherlands has become increasingly negative towards migration from poorer non-EU countries since at least the mid 1990s.

Social surveys provide clear indications of an increasingly negative public opinion regarding immigration from non-Western countries, especially for the period in which immigration detention increased the most. The European Social Survey (ESS), which has been carried out four times since 2002, includes the question to what extent 'migrants from poorer countries outside Europe should be allowed [to live in the country]'. In 2002, 43\% of the Dutch respondents $(\mathrm{N}=2,364)$ answered 'a few' or 'none'. In $2004(\mathrm{~N}=1,881)$ and $2006(\mathrm{~N}=1,889)$ that share increased to $47 \%$ and $53 \%$. Interestingly, in 2008 that percentage had returned to the 2002 level $(43 \%, \mathrm{~N}=1,778)$, paralleling the political decision to legalise about 30,000 rejected asylum seekers and the decreased use of administrative immigration detention after 2006 (Figure 1). Additional indications for a negative public opinion towards (illegal) immigration can be found in the International Social Survey Program (ISSP). As part of the ISSP, two representative surveys on 'national identities' were carried out, in 1995 and 2003 respectively. In 1995, $37 \%$ of the Dutch respondents $(\mathrm{N}=1,823)$ agreed or agreed strongly that immigrants increase crime rates. In 2003 this percentage had gone up to $45 \%(\mathrm{~N}=2,089)$. Also, in 1995 a large majority (81\%) agreed or agreed strongly that the government should take

stronger measures to exclude illegal migrants. In 2003 this percentage remained unchanged, even though the Dutch government had in fact taken several measures 
between 1995 and 2003 to curb illegal residence. Thus, public pressure on the government to 'do something' about illegal migration clearly persisted in the face of an increasingly restrictive policy towards illegal migrants.

It is against this background of popular opinion that we hypothesise that immigration detention is not only intended to facilitate expulsion (the formal framework for immigration detention) and migration decisions (our hypothesis about immigration detention's covert function of deterring illegal residence); it also seems to have the function to regulate the more abstract social unrest regarding unwanted migration. The increase in immigration detention communicates the message that the State is still in control over the geographical (and social) borders that citizens want to maintain. Admittedly, the poor relief function of administrative detention, which was discussed in the previous section, also addresses social unrest to some extent, but social unrest in connection with pauperism must be distinguished from the more abstract and generalised anxiety about unwanted immigration that concerns us here. This third informal function of immigration detention is akin to the function of punishment as denunciation: it expresses the value that there should be borders demarcating the divide between who belongs to the society and who does not.

Compared to the other informal functions, the denunciation function may be relatively latent, i.e. relevant actors may not realise - or at least openly admit - that immigration detention is functional for denunciation. For this reason, empirical evidence is bound to remain somewhat speculative.

It is clear, however, that an increase in immigration detention is, par excellence, useful to appease citizens about unwanted migration: detention symbolises social exclusion in a straightforward way. Bosworth (quoted in Lee 2007: 850) puts it as follows: "[t]he point is that prisons and detention centers ... are singularly useful in the management of non-citizens because they provide both a physical and a symbolic exclusion zone'. Zygmunt Bauman also characterises modern prisons as 'factories of exclusion' and links them with political reactions to popular sentiments: "To posit imprisonment as the crucial strategy in the fight for citizen's safety means addressing the 
issue in a contemporary idiom, using language readily understood and invoking commonly familiar experience" (Bauman 1998: 121).

Foucault (1977) is well-known for his argument that pre-modern punishments symbolised and glorified the political power of the Monarch. If we are right, immigration detention is - albeit to a more limited extent and with a more modern dramaturgy - being used to symbolise the power of the national State in times of heightened globalisation. In that respect, it is interesting to note that centres for immigration detention - especially the more punitive regimes for men - are spatially overrepresented in the $\underline{\text { Randstad, the }}$ densely populated Western part of the Netherlands. In contrast to this, reception centres for asylum seekers - which send a different message as asylum seekers may be admitted

to the Netherlands - tend to be located in sparsely populated areas. ${ }^{13}$ Moreover, it appears that most centres for immigration detention symbolise departure in one way or another. Several centres are located near airports (Schiphol and Rotterdam airport). Admittedly, this may be practical with an eye to expulsion. Yet, other centres are located near harbours (Rotterdam and Dordrecht), even if no expulsions are carried out by sea. In addition, in recent years several centres for immigration detention have been built in the form of detention boats (Rotterdam, Dordrecht, Zaandam). The official reason for the construction of these boats was that it was a quick way to increase the detention capacity, but this raises the question of whether there were no other ways to do so, for instance by building centres in less populated areas, and why no detention boats were built to accommodate the increased need for criminal detention capacity. The boats are now being closed, partly in response to a report by Amnesty International (2008), which criticised the human rights situation on the boats, and because of the recent decrease in the number of detained illegal migrants as a consequence of the EU-enlargements.

There is a final indication for the denunciation function of immigration detention: whereas the expansion of immigration detention capacity was quite well-communicated to the public, information on expulsion trends is certainly not. ${ }^{14}$ The latter information is, as we mentioned in section 3, deeply buried in Ministry of Justice reports, which are not characterised by a very transparent presentation of expulsion figures, to say the least.

\section{Discussion: mixed motives for administrative immigration detention?}


Immigrant detention in the Netherlands indeed constitutes a case of mixed motives. Its formal function is still firmly upheld, but does not explain detention practices completely. It has to be said though, that EU member states, including the Netherlands, have been investing heavily in the construction of new biometric identification systems to 'break down the anonymity' of illegal migrants (see Broeders 2007, 2009). This may strengthen the formal function by increasing the number and speed of successful expulsions.

Three informal functions have been discussed: (1) deterring illegal residence, (2) controlling pauperism and (3) symbolically asserting state control. There is an elective affinity between the functions mentioned. In many cases the functions need, and reinforce, each other. For example, in order to address social unrest about unwanted immigration, expulsions should occur, and immigration detention should try to deter illegal residence, but it also helps if nuisance-causing illegal migrants are kept of the street. There is, however, a tension between expulsion, deterrence and the management of popular anxiety on the one hand, and poor relief on the other hand. If administrative detention becomes too 'comfortable' the incentive to co-operate with repatriation is greatly reduced, and the general public will not be convinced that the state is in control over unwanted migration. If, however, immigration detention becomes too harsh, it will give cause for humanitarian objections, but will also worsen health and behavioural problems among 'cobbled' detainees, thus giving rise to more public order problems and more public anxiety about immigration. For this reason, it is likely that a certain balance between punitive and more humanitarian concerns is and will be considered necessary.

The informal functions mentioned have, in part, developed in relation to the phenomenon of the 'undeportable deportable alien'. This suggests that the institution of immigration detention, like immigration policy in general, is in flux: modern society has not yet found a definitive solution for the presence of migrants who are formally not admitted, but are also difficult to expel. Mixed motives for administrative detention are to some extent the result of different actors - state authorities, local authorities, citizens, illegal migrants - using detention for their own purposes.

There are clear analogies between the three informal functions of immigration detention and the functions of punishment described by the academic literature. Firstly, 
there is deterrence in immigration detention, even if it is aimed at influencing migration decisions rather than at deterring criminality as usually defined. Secondly, there is incapacitation, even if illegal migrants qualify for incapacitation more easily than citizens and legal denizens, where minor offences and pauperism usually do not lead prolonged periods of detention. Thirdly, there is denunciation, though not primarily in connection with social values that obtain regardless of legal status - this tends to be more typical of criminal law - but rather in connection with values that are specifically related to 'unwanted' outsiders, expressing the condemnation of immigration and residence without the consent of the body politic.

These analogies question the seemingly clear-cut division between criminal and administrative law. In this connection, our analysis confirms De Giorgi's (2006: 133) claims that practices of detention and expulsion of immigrants are 'formally administrative' yet 'concretely penal', an opinion that is echoed in Ericson's (2007: 25) notion of 'counter law' in which "the traditional distinctions between the different legal forms of criminal, civil and administrative law" have become blurred. We have shown that there also is a blurring between different types of administrative law in so far as immigration detention regulates pauperism, which, in the legal population, is not controlled by detention to the same extent, and is usually dealt with under administrative law (rules about access to public homeless shelters, unemployment benefits).

The analogies raise the question of why immigrant detention is not integrated in criminal law, and why it tends to be dealt with under administrative law even in countries where illegal residence is defined as a crime (such as Germany). We propose that the explanation lies in two aspects of punishment that are less central in immigration detention. Firstly, the full incorporation in criminal law risks being at odds with the sense of justice and proportionality that underlies notions of punishment as retribution. A detention lasting three, six or even eighteen months on account of the 'mere' crime of illegal residence would contrast strongly with the major - for example violent - crimes usually leading to such a (lengthy) sentence. It would bring illegal residence into a 'league' of crime where it does not belong according to most citizens, but especially in the eyes of criminal judges, academics, human rights organisations, and advocacy groups. In this sense, administrative law provides the authorities with a flexible instrument of 
control (in terms of length of detention) that would probably be difficult to obtain under criminal law. If immigration detention would be completely transferred to the latter body of law, Western societies would have to admit that different standards of punishment and governmental control pertain to citizens and (unwanted) non-citizens (see also Walters 2002, Sayad 2004). In the legal and official policy discourse, this difference remains more hidden and implicit (cf. Bosworth, 2007).

A second obstacle to incorporating illegal residence into criminal law is that it would necessitate the application of a reintegration ideology for offenders committing the 'crime' of illegal residence. Dutch penitentiary law, for example, stipulates that the penitentiary program is supposed to increase the chances of involvement in the regular labour market after release. Such ideals of reformation, even if less pronounced now than a few decades ago, would contradict the official objective of expulsion that is inherent in the legal construction of an 'illegal alien'. Whereas a 'deviant' citizen is supposed to have opportunity to re-earn the status of a 'normal' citizen (this is true for convicts and for other institutionalized groups, such as drug addicts and psychiatric patients), detained illegal migrants are supposed to leave the (national) society, even if it would be possible and - in the case of criminal illegal migrants - deemed necessary to reform the detainee. (It is conceivable that penitentiary programs would assist reintegration in the country of origin rather than in the country of detention, but so far this is not happening.)

In the future we may see a greater $\underline{\text { de facto }}$ and de jure differentiation in immigration detention. Some informal punitive aspects may become integrated in criminal law, for example by making repeated illegal residence a punishable offense. At the same time, less punitive aspects may be organised in a system of control that is less modelled after criminal detention. While 'undeserving' illegal migrants - i.e. male illegal migrants, criminal illegal migrants, illegal migrants not co-operating with expulsion - are likely to be criminalised further (not only de facto, but also de jure), their 'deserving' counterparts may become decriminalised to a greater extent. Should such a development materialise, that would not be the first time in the history of the prison that institutional differentiation occurred: from the houses of correction, for instance, grew both the modern prison and the more humanitarian poor house (cf. Morris and Rothman 1998). 
There are, in fact, a number of indications that this differentiation is already underway, both in the Netherlands and elsewhere. We already mentioned the gender difference in immigration detention regimes in the Netherlands and pointed at the increase in the number of aliens that are declared undesirable. Besides this, it is relevant to note that in 2006 the Dutch government started an experiment with what is called an onderdaklocatie ('shelter location'). In this open centre, where clients can stay a maximum of twelve weeks, illegal migrants are not detained but nonetheless controlled: they have to report themselves to the authorities regularly. Tellingly, the institution is reserved for rejected asylum seekers who no longer have a right to stay in the Netherlands and are believed to be willing to co-operate with 'voluntary return'. Furthermore, in December 2009 a one year experiment was started with a nationally funded centre for the temporary relief of rejected asylum seekers who are seriously ill, and who have not yet managed to obtain a temporary residence permit on that ground. Likewise, in the United States, after complaints by civil liberties and immigrant advocacy groups (see Amnesty International 2009), the Immigration and Customs Enforcement (ICE) has recently declared its intentions to hold 'non-criminal immigrants [our emphasis] in a smaller number of less prison-like settings'. ${ }^{15}$

\section{Acknowledgements}

We thank two anonymous reviewers for their thoughtful comments. Arjen Leerkes is supported by a VENI research grant from the Netherlands Organization for Scientific Research (NWO). 


\section{References}

ACVZ (2002), Vreemdelingen in bewaring. Advies over vreemdelingenbewaring en verwijdering van 'criminele' vreemdelingen. Den Haag: Adviescommissie voor Vreemdelingenzaken.

Amnesty International (2008), The Netherlands: the Detention of Irregular Migrants and Asylum-seekers. Amsterdam: Amnesty International.

Amnesty International (2009) Jailed Without Justice: Immigration Detention in the USA. New York: Amnesty International.

Autonoom Centrum (2004), Over de grens. Verwijdering van vluchtelingen en migranten uit Nederland. Amsterdam: Autonoom Centrum.

Baldaccini, A. (2009), 'The Return and Removal of Irregular Migrants under EU Law: an Analysis of the Returns Directive', European Journal of Migration and Law, 11/1: 117.

Bauman, Z. (1998), Globalisation. The Human Consequences. Cambridge: Polity.

Blumer, H. (1954), 'What is Wrong with Social Theory?' American Sociological Review, 19/1: 3-10.

Bosworth, M. (2007), 'Creating the Responsible Prisoner: Federal admission and orientation packs', Punishment \& Society, 9: 67-85.

Broeders, D. (2007), 'The New Digital Borders of Europe. EU Databases and the Surveillance of Irregular Migrants', International Sociology, 22: 71-92. 
Broeders, D. (2009), Breaking Down Anonymity Digital Surveillance of Irregular Migrants in Germany and the Netherlands, Amsterdam: Amsterdam University Press.

Broeders, D. (2010), 'Return to sender? Administrative detention of irregular migrants in Germany and the Netherlands', Punishment \& Society, 12: 169-186.

Burke, A. (2008), Fear of Security: Australia's Invasion Anxiety. Cambridge: Cambridge University Press.

Calavita, K. (2005), Immigrants at the Margins. Law, Race, and Exclusion in Southern Europe. Cambridge: Cambridge University Press.

Carlsmith, K. and J. Darley (2002). 'Why do we punish?: Deterrence and just deserts as motives for punishment'. Journal of Personality and Social Psychology, 83/2: 284-299.

Cheliotis, L. (2006), 'How Iron Is the Iron Cage of New Penology? The Role of Human Agency In The Implementation of Criminal Justice Policy', Punishment \& Society, 8/3: 313-340.

Cornellise, G. (2010), Immigration Detention and Human Rights: Rethinking Territorial Sovereignty. Leiden and Boston: Martinus Nijhoff.

De Giorgi, A. (2006), Re-thinking the Political Economy of Punishment. Perspectives on Post-Fordism and Penal Politics. Aldershot: Ashgate Publishing.

De Haas, H. (2005), 'International migration, remittances and development: myths and facts', Third World Quarterly, 26/8: 1269-1284.

Den Hollander, R. (2004), 'Uitzetcentra: vreemdelingendetentie ter fine van verwijdering', Proces, 4: 159-166. 
DJI (2004), DJI Jaarbericht 2003. De feiten, factoren en afwegingen. The Hague: Dienst Justitiële Inrichtingen.

DJI (2008), Vreemdelingenbewaring in Nederland. Survey onder vreemdelingen naar het verblijf binnen de inrichting. The Hague: DJI..

DJI (2008), Annual Report 2007. The Hague: DJI.

Dünkel, F., A. Gensing and Morgenstern, C. (2007) , 'Germany', in A. Van

Kalmthout, F. Hofstee-van der Meulen \& F. Dünkel, eds., Foreigners in European Prisons. Volume 1, 343-390. Nijmegen: Wolf Legal Publishers.

Ellermann, A. (2005), 'Coercive Capacity and the Politics of Implementation. Deportation in Germany and the United States', Comparative Political Studies, 38/10: 1219-1244.

Ellermann, A. (2008), 'The Limits of Unilateral Migration Control: Deportation and Interstate Cooperation, Government and Opposition, 32/2: 168-189.

Ericson, R. (2007), Crime in an Insecure World, Cambridge: Polity Press.

Feely, M. and Simon, J. (1992), 'The New Penology: Notes on the Emerging Strategy of Corrections and Its Implications', Criminology, 30/4: 449-474

Foucault, M. (1977), Discipline and Punish: the Birth of the Prison. New York: Pantheon Books.

Garland, D. (1991), 'Sociological perspectives on punishment', Crime and Justice 14: 115-165. 
Garland, D. (2001), The Culture of Control: Crime and Social Order in Contemporary Society. Oxford: Oxford University Press.

Gibney, M. and Hansen, R. (2003), Deportation and the Liberal State: The Forcible $\underline{\text { Return of Asylum Seekers and Unlawful Migrants in Canada, Germany and the United }}$ Kingdom, New issues in refugee research, working paper no. 77, Geneva: UNHCR

Hailbronner, K. (2007), 'Detention of Asylum Seekers', European Journal of Migration and Law, 9/2: 159-172.

Inda, J. (2006) 'Border prophylaxis. Technology, illegality and the Government of immigration', Cultural Dynamics, 18/2: 115-138.

International Organisation for Migration (IOM) (2008), Out of Sight. Research into the Living Conditions and Decision Making Process of Irregular Migrants in the Main Cities of The Netherlands, Germany and Austria. The Hague: IOM.

Jesuit Refugee Service (2005), Detention in Europe. Administrative Detention of

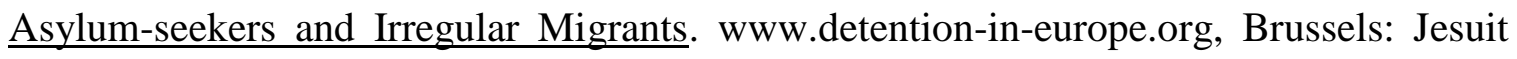
Refugee Service (JRS) - Europe.

Katz, M. (1986), In the Shadow of the Poorhouse: A Social History of Welfare in America. New York: Basic Books.

Lee, M. (2007), ‘Women’s Imprisonment as a Mechanism of Migration Control in Hong Kong', British Journal of Criminology, 47/6: 847-860.

Leerkes, A. (2009) Illegal Residence and Public Safety in the Netherlands, Amsterdam: Amsterdam University Press. 
Leerkes, A. and W. Bernasco (2010), 'The spatial concentration of illegal residence and neighborhood safety', Journal of Urban Affairs, 32 (3) 367-392

Leerkes, A. and D. Broeders (2010), 'A question of mixed motives? Formal and informal functions of administrative immigration detention', British Journal of Criminology 50 (5): 830-850.

Levy, M. (1968), 'Structural-functional analysis' in D. Sills, International Encyclopedia of the Social Sciences, 21-28. The Macmillan Company \& The Free Press.

Merton, R. (1957), 'Manifest and Latent Functions', in: Social Theory and Social Structure, 19-84. Glencoe, Ill.: The Free Press,

Minister voor Vreemdelingenzaken en Integratie (2003) Terugkeernota. Maatregelen voor een effectievere uitvoering van het terugkeerbeleid. TK, vergaderjaar 2003-2004, 29 $344, \mathrm{nr} .1$

Ministry of Justice (2005), Rapportage Vreemdelingenketen 2004. The Hague: Ministry of Justice.

Ministry of Justice (2006), Rapportage Vreemdelingenketen 2005. The Hague: Ministry of Justice.

Ministry of Justice (2007), Rapportage Vreemdelingenketen 2006, over de periode September t/m december 2006. The Hague: Ministry of Justice.

Ministry of Justice (2008), Rapportage Vreemdelingenketen 2007, periode juli-december 2007. The Hague: Ministry of Justice.

Ministry of Justice (2009), Rapportage Vreemdelingenketen, periode januari-juni 2009. The Hague: Ministry of Justice. 
Morris, N. and Rothman, D. (Eds.) (1998), The Oxford History of the Prison: The Practice of Punishment in Western Society. Oxford: Oxford University Press.

Noll, G. (1999), 'Rejected Asylum Seekers: The Problem of Return', International Migration, 37/1: 267-288.

Reiner, R. (2007), Law and Order. An Honest Citizen's Guide to Crime and Control. Cambridge: Polity Press.

Rusinovic, K., Van der Leun, L., Chessa, T., Weltevrede, A., Engbersen, G., and Vos, J. (2002), Nieuwe vangnetten in de samenleving. Over problemen en dilemma's in de opvang van kwetsbare groepen. Rotterdam: Erasmus University / RISBO.

Rychlak, R. (1990), 'Society's Moral Right to Punish: A Further Exploration of the Denunciation Theory of Punishment', Tulane Law Review, 65: 299-324.

Sayad, A. (2004), The Suffering of the Immigrant. Cambridge: Polity.

Scalia, J. (2002), Immigration Offenders in the Federal Criminal Justice System, 2000.

Washington, D.C.: US Department of Justice, Bureau of Justice Statistics.

Tweede Kamer (2002), Vaststelling van de begrotingsstaat van het Ministerie van Justitie (VI) voor het jaar 2003. Kamerstuk 28600 VI. The Hague: Tweede Kamer.

Van der Heijden, P., Van Gils, G., Cruijff, M., Hessen, D. (2006), Een schatting van het aantal in Nederland verblijvende illegale vreemdelingen in 2005. The Hague: WODC.

Van Kalmthout, A. (2005), 'Vreemdelingenbewaring', in E. Muller and P. Vegter (Eds.), Detentie. Gevangen in Nederland, 321-343. Kluwer: Alphen aan den Rijn. 
Van Kalmthout, A. (2007), 'Het regiem van de vreemdelingenbewaring', Justitiële Verkenningen, 33/4: 89-102.

Van Kalmthout, A., and Van Leeuwen, K. (2004), Terugkeermogelijkheden van vreemdelingen in de vreemdelingenbewaring. Deel 1: de vreemdelingenbewaring in Tilburg en Ter Apel; het dossieronderzoek. Nijmegen: Wolf Legal Publishers.

Van Kalmthout, A. and K. Van Leeuwen (2004), Terugkeermogelijkheden van vreemdelingen in vreemdelingenbewaring. Deel 2: Evaluatie terugkeerprojecten. Nijmegen: Wolf Legal Publishers

Van Kalmthout, A. and Hofstee-van der Meulen, F. (2007), 'Netherlands', in A. Van Kalmthout, F. Hofstee-van der Meulen and F. Dünkel, eds., Foreigners in European prisons. Volume 2, 623-660. Nijmegen: Wolf Legal Publishers.

Van Kalmthout, A., Hofstee-van der Meulen, F., and Dünkel, F. (2007), 'Comparative Overview, Conclusions and Recommendations', in A. Van Kalmthout, F. Hofstee-van der Meulen and F. Dünkel, eds., Foreigners in European prisons. Volume 1, 7- 88. Nijmegen: Wolf Legal Publishers.

Van der Leun, J. (2003), Looking for Loopholes. Processes of Incorporation of Illegal Immigrants in the Netherlands. Amsterdam: Amsterdam University Press.

Van der Leun, J. (2004), Lokale solidariteit met illegale migranten, in H. Entzinger and J. Van der Meer, eds., Grenzeloze solidariteit. Naar een migratiebestendige verzorgingsstaat, 73-85. Amsterdam: De Balie.

Wacquant, L. (1999), “'Suitable Enemies”. Foreigners and Immigrants in the Prisons of Europe', Punishment \& Society, 1/2: 215-222.

Wagner, D. (2005), The Poorhouse: America's Forgotten Institution. Lanham: Rowman 
\& Littlefield Publishers.

Walters, W. (2002), 'Deportation, Expulsion, and the International Police of Aliens', Citizenship Studies, 6/3: 265-292.

Weber, L. and Bowling, B. (2004), 'Policing Migration: a Framework for Investigating the Regulation of Global Mobility', Policing \& Society, 14/3: 195-212.

Welch, M. and Schuster, L. (2005), 'Detention of asylum seekers in the US, UK, France, Germany and Italy: A critical view of the globalizing culture of control', Criminal Justice, 5/4: 331-355. 
Figures

Figure 1: Administrative detention and expulsions in the Netherlands, 19992007

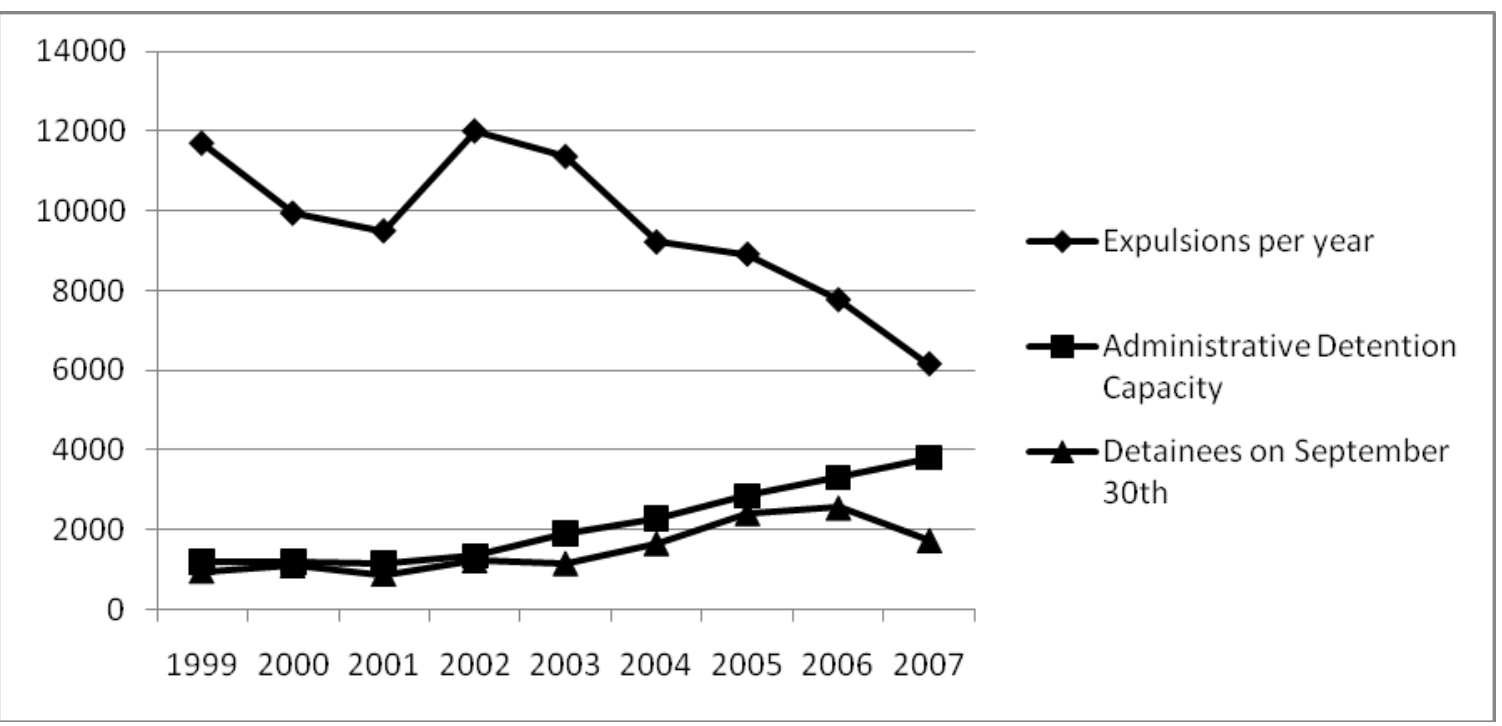

Source: Detention capacity 1999-2002 from DJI (2004), detention capacity data 20032007 from DJI (2008a). Data on number of detainees on September 30th from Statistics Netherlands, http://statline.cbs.nl (visited October 2009). Data on expulsions 1999-2001 from Immigration and Naturalisation Service (cited by Autonoom Centrum (2004)); data on expulsions 2002-2004 from Ministry of Justice (2005), expulsions 2005 from Ministry of Justice (2006), expulsions 2006 (Ministry of Justice 2007: 42), expulsions 2007 Ministry of Justice (2008a: 21, 2008b: 19). 
Figure 2: Detention satisfaction among administratively detained illegal migrants (2004 and 2007 combined) and regular prisoners (2007) by sex

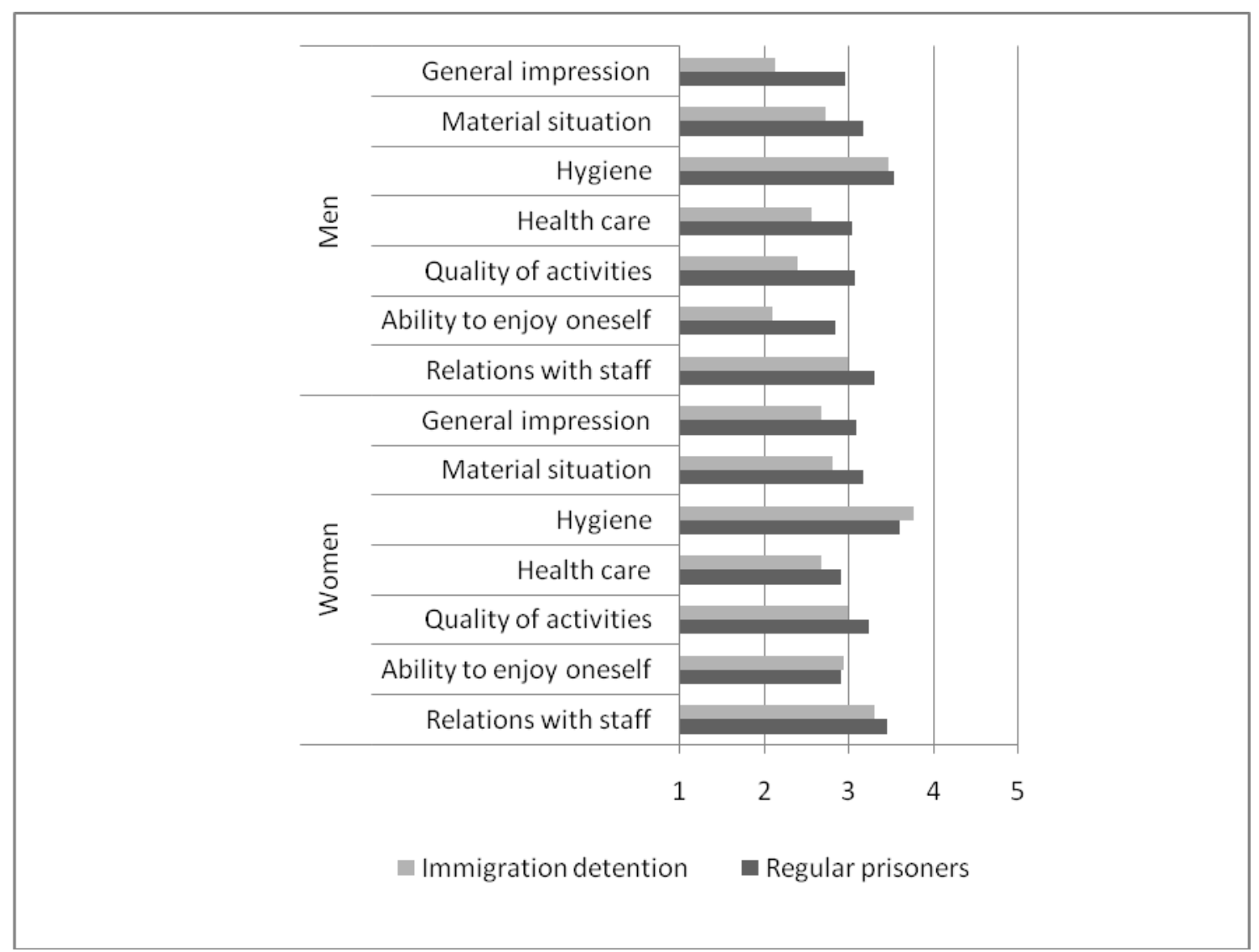

Source: DJI Vreemdelingensurvey 2004, DJI Vreemdelingensurvey 2007, and DJI Gedetineerdensurvey 2007. 


\section{Figure 3. Feelings of unsafety among administratively detained illegal migrants (2004 and 2007 combined) and regular prisoners (2007) by sex}

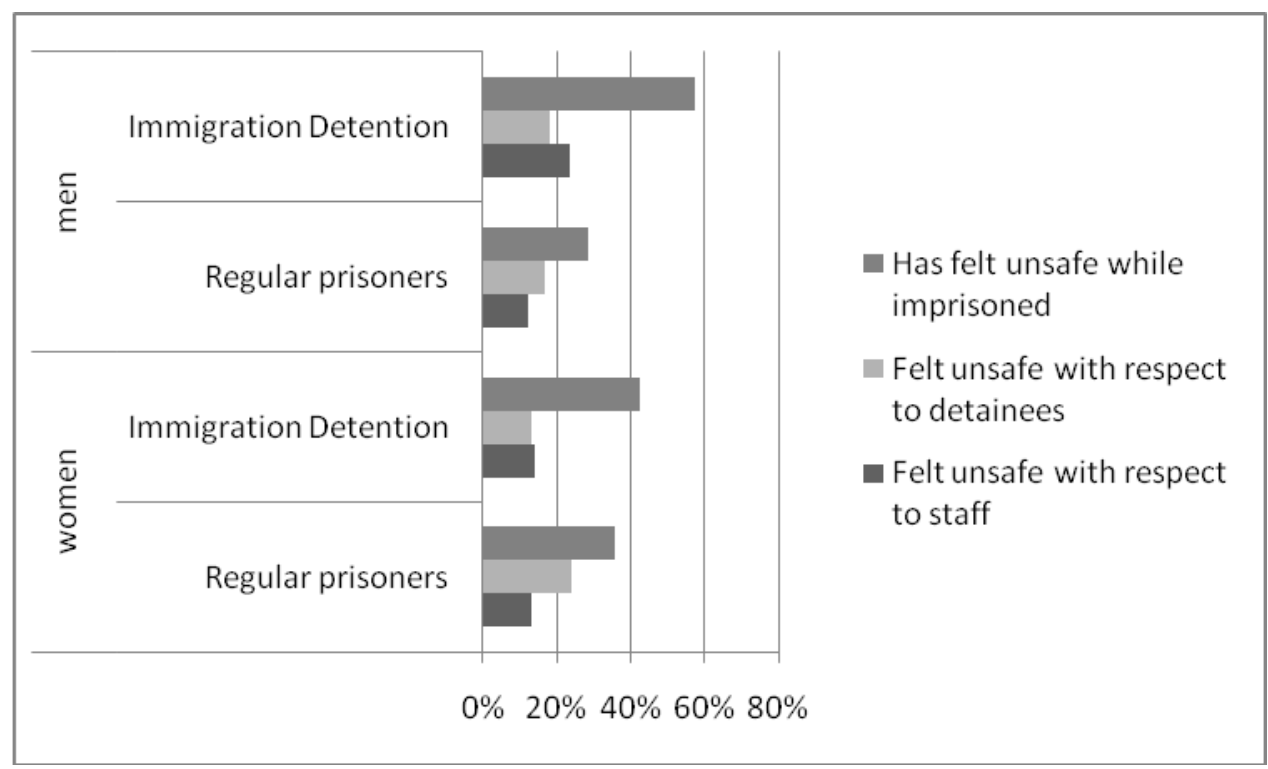

Source: DJI Vreemdelingensurvey 2004, DJI Vreemdelingensurvey 2007, and DJI Gedetineerdensurvey 2007.

${ }^{1}$ Dutch Alien Law 2000, clause 59.

${ }^{2}$ Detention may also be annulled when immigration authorities anticipate that an administrative judge will decide to annul, or when the acting immigration officer considers continued detention unlawful.

3 Research by Van Kalmthout and Van Leeuwen (2004: 60) suggested that at least 29 per cent of the administratively detained migrants have been detained repeatedly. The authors base this on the checklist used by the government to record information about the alien, filled in by the local aliens police. Out of 329 respondents who were researched by Van Kalmthout and Van Leeuwen, 95 respondents (29 per cent) had been previously presented, thirteen respondents (4 per cent) had not and there were no data available for 221 respondents ( 67 per cent). Repeated immigration detention is allowed if a year has expired after a former period of detention has ended, or if new facts or circumstances occur that may lead to expulsion.

4 Germany, Finland, Ireland, France, Cyprus, and, since 2009, Italy.

5 Source for 1994 figure: Statistics Netherlands, http://statline.cbs.nl, visited January 2010. Source 2006 figure: Dienst Justititiële Inrichtingen, http://www.dji.nl, visited April 2010. 
${ }^{6}$ Source: http://www.dji.nl, visited April 2010.

7 In 2007, the average costs for immigration detention per place per day were 155 euro, against 197 euro in regular prisons (DJI, 2008: 61).

8 Before becoming a cabinet minister, Mr. Nawijn had a career in the Dutch civil service at the department of Justice. He held various positions in the field of immigration policy, lastly as director of the Immigration and Naturalisation Service (IND).

9 In 2004622 illegal migrants participated in the survey, and in 2007 575; in 2007 the number of respondents in regular prisons was 6,020. We are thankful to the National Agency of Correctional Institution's (DJI) for making the data available to us in order to conduct secondary analyses. ${ }^{10}$ About two third (68\%) of the administratively detained females who participated in the Vreemdelingensurvey 2004 or Vreemdelingensurvey 2007 had a shower in their cell. against halve (51\%) of the males. About a quarter of the females (24\%) had to share a cell with more than one person, against $46 \%$ of the males.

${ }^{11}$ The scale 'material situation' (Cronbach's alpha $=.74$; listwise missing $=14 \%$ ) is the average of the scores for the items 'I get enough to eat', 'I am satisfied about the quality of the products in the shop', 'I can buy in the shop what I need', 'Warm food has the right temperature', 'I am satisfied about the eating times', 'I think the warm food is tasty', 'They take religious beliefs into account for the meals'. The scale 'hygiene' (alpha $=.71$; listwise missing $=11 \%$ ) is the average of the scores for the items 'It is clean on my unit', 'The showers are clean', 'the air space is clean', 'I can get my clothes cleaned sufficiently regularly', 'I can shower sufficiently regularly'. The scale 'health care' (alpha $=.73$; listwise missing $=18 \%$ ) is the average of the scores for the items ' $I$ have been wellinformed in this institution about contagious diseases (such a STD's, aids, jaundice)', 'I can get tested easily (for example for aids and hepatitis) if I want to', 'If I want to I can go to the doctor in this institution', 'I am satisfied about the work of the doctor', 'I am satisfied about the work of the nurse'. The scale 'quality of activities' (=.79; listwise missing $=21 \%)$ is the average of the scores for the items 'I am satisfied about the sporting facilities', 'I am satisfied about the library', 'I am satisfied about labour facilities', 'I am satisfied about creative facilities'. It is probable that administratively detained migrant are even more negative about the quality of activities than the scores on this scale suggest. For this scale the number of missing values among the latter migrants is quite high (35\%), which may be due to the fact that several administratively detained respondents did not have access to labour and creative facilities. The scale 'ability to enjoy oneself' (alpha $=.75$; listwise missing $=18 \%$ ) is the average of the scores for the items ' $I$ can enjoy myself in my cell', 'I can spend my free time with things that I like', 'In the evenings I have enough to do'. The scale 'relations with staff' (alpha $=.86$; listwise missing $=14 \%$ ) is the average of the scores for the items 'The personnel will help me if I have problems', 'The personnel are friendly to me', 'If I am down, I can talk with the personnel', 'The personnel treat me in a normal way'. 
${ }^{12}$ In 1991, for instance, the use of social-security numbers was barred for illegal migrants, which made it much more difficult for them to work in the formal economy. In 2005, the fine for employers who hired illegal aliens was raised from 900 to 8,000 euro per employee, and since the late 1990 s the government increasingly allocated resources to enforce employer sanctions.

${ }_{13}$ The latter centres are often located in out of the way places, on industrial zones or in abandoned military complexes; this is also done to discourage societal integration in light of the fact that the majority of the asylum claims will be rejected.

14 The government's press release of November $5^{\text {th }} 2004$, which highlights the results of the Ministry's of Justuce report Rapportage Vreemdelingenketen 2004, periode mei tot en met augustus, is a fairly typical example (see http://www.regering.nl/Actueel/Pers_en_nieuwsberichten/2004/November/o5/Rapportage_in stroom_asielzoekers_daalt.). The press release starts with stressing the decrease in the number of migrants applying for political asylum (in the period May-August 2004 there were 34\% fewer applications compared to the same period in 2003). Later on, the release mentions the increase in the capacity for administrative immigration detention and also lists the number of deported illegal migrants in the period May-August 2004. The release does not - contrary to the figures on asylum applications - mention that the number of expulsions decreased since 2003.

${ }_{15}$ Source: Washington Post, August 7, 2009. 